NBER WORKING PAPER SERIES

\title{
CAPITAL CONTROLS: A SURVEY OF THE NEW LITERATURE
}

\author{
Alessandro Rebucci \\ Chang Ma \\ Working Paper 26558 \\ http://www.nber.org/papers/w26558
NATIONAL BUREAU OF ECONOMIC RESEARCH
1050 Massachusetts Avenue
Cambridge, MA 02138 \\ December 2019
}

Paper prepared for the Oxford Research Encyclopedia of Economics and Finance. For useful comments and discussions, we are grateful to the Editor (Kenneth Kletzer), an anonymous referee, Gianluca Benigno, Kristin Forbes, Michael Klein, Anton Korinek, and Nico Magud. Alessandro Rebucci gratefully acknowledges financial support from the Johns Hopkins Catalyst Award Grant Program. Chang Ma gratefully acknowledges financial support from the Shanghai Pujiang Program. The usual disclaimers apply. The views expressed herein are those of the authors and do not necessarily reflect the views of the National Bureau of Economic Research.

NBER working papers are circulated for discussion and comment purposes. They have not been peer-reviewed or been subject to the review by the NBER Board of Directors that accompanies official NBER publications.

(C) 2019 by Alessandro Rebucci and Chang Ma. All rights reserved. Short sections of text, not to exceed two paragraphs, may be quoted without explicit permission provided that full credit, including $(\odot$ notice, is given to the source. 
Capital Controls: A Survey of the New Literature

Alessandro Rebucci and Chang Ma

NBER Working Paper No. 26558

December 2019

JEL No. F38,F41

\begin{abstract}
$\underline{\text { ABSTRACT }}$
This paper reviews selected post-Global Financial Crisis theoretical and empirical contributions on capital controls and identifies three theoretical motives for the use of this policy tools: pecuniary externalities in models of financial crises, aggregate demand externalities in new-Keynesian models of the business cycle, and terms of trade manipulation in open economy models with pricing power. Pecuniary and demand externalities offer the most compelling case for the adoption of capital controls, but macroprudential policy can also address the same distortion. So, in general, capital controls are not the only instrument that can do the job. If evaluated through the lenses of the new theories, the empirical evidence reviewed suggests that capital controls can have the intended effects, even though the extant literature is inconclusive as to whether the effects documented amount to a net gain or loss for the economies that adopted these policies. Terms of trade manipulation also provides a clear cut theoretical case for the use of capital controls, but this motive is less compelling because of the spillover and coordination issues inherent with the use of control on capital flows for this purpose.
\end{abstract}

\author{
Alessandro Rebucci \\ Johns Hopkins Carey Business School \\ 100 International Drive \\ Baltimore, MD 21202 \\ and NBER \\ arebucci@jhu.edu \\ Chang Ma \\ Fudan University, \\ Fanhai International School of Finance \\ Shanghai 200433 \\ CHINA \\ machang.china@gmail.com
}




\section{Background and Motivation}

One lesson learned from the Global Financial Crisis (GFC) and the accompanying great recession of 2007-2009, as well as the emerging market crises of the 1990s and the 2000s, is that financial crises are very difficult and costly to resolve - see, for instance, Rogoff and Reinhart (2009) and Cerra and Saxena (2008). As a result of these dramatic experiences, academic interest has turned to policies aimed at preventing financial crises, including the so-called macroprudential policies and capital controls. On the policy front, crisis-prevention policies had been discussed in international policy circles at least since the Asian crisis, but only more recently the leading international organizations and central banks have become more open to consider the prudential use of older-fashioned capital controls that discriminate between residents and non-residents. The IMF, in particular, historically a strong supporter of free capital mobility, changed its institutional view in 2012 - e.g., IMF (2012) — adopting a more open-minded attitude toward these policies.

The extant pre-GFC literature on capital controls was mostly empirical and not firmly grounded in theory. It also tended to conclude that these instruments are not effective and possibly costly. For example, in their survey, Magud, Reinhart, and Rogoff (2018) identify four rationales for the use of capital controls: (i) fear of appreciation; (ii) fear of hot money; (iii) fear of large inflows; and (iv) fear of loss of monetary autonomy - all based on observable policy objectives. In a meta-analysis of close to 40 papers, they conclude that capital controls may provide some space for monetary policy independence and may be able to alter the composition of capital flows. However, capital controls alone (i.e., without reserve accumulation) did not seem effective at managing the real exchange rate in the face of excessive upward or downward pressures or at affecting total flows.

The post-GFC literature on capital controls is grounded in theory more firmly. The focus of the new theoretical literature is on alternative justifications for the adoption of capital controls and the analysis of the welfare gains associated with their optimal use in calibrated general equilibrium models. The new empirical literature describes policies pursued by governments and also aims at quantifying the causal effects of controls (in partial equilibrium settings) on observable variables identified in the policy debate, or featuring the theoretical models.

This survey reviews post-GFC theoretical and empirical contributions on capital controls. To the extent possible, the survey focuses on capital controls narrowly defined. In particular, in this paper, the term "capital controls" refers to quantity- or price-based restrictions on financial asset and liability transactions (i.e., purchases or sales) between residents and non-residents. It is important to note here that capital controls so defined are a narrower set of the so-called 
"capital flow management" measures (CFMs). The latter also includes restrictions and regulations on foreign exchange denominated instruments or other financial instruments that may affect capital flows and the exchange rate, but do not discriminate between residents and nonresidents - see IMF (2012) for specific CFM examples. As a consequence, this survey covers mostly theoretical and empirical contributions that focus on capital controls narrowly defined, even though papers on macroprudential policy more broadly defined will be discussed to the extent to which they are critical for the exposition. ${ }^{1}$

The discussion of the theoretical contributions is organized around alternative justifications for the adoption of capital controls. The first group of papers focuses on financial stability concerns arising from pecuniary externalities in models of financial crises with occasionally binding borrowing constraints. A second group includes contributions that justify capital controls as a means to address aggregate demand deficiency when monetary policy is constrained in New-Keynesian models of the business cycle, giving rise to the so-called demand externalities. Under this heading also falls the discussion of papers that justify the use of capital controls with the time-honored issue of the trilemma of international finance, i.e., papers that justify capital controls with the desire of seeking or preserving monetary policy independence. There is also a portion of the new theoretical literature that analyzes capital controls, together with monetary or exchange rate policy, in the presence of both pecuniary and demand externalities. A last group of papers motivates capital controls with the objective of affecting the terms-of-trade open economies with pricing power. The discussion of the new empirical literature is organized around two lines. The first concentrated on describing what capital control policies countries pursue. The second on the traditional question of capital controls effectiveness. The paper also highlights and discusses references for further reading and on this topic and promising areas of future research. The lessons learned are summarized in the concluding section.

\section{Capital Controls and Pecuniary Externalities}

In a series of recent papers, capital controls have been proposed as a macroeconomic policy tool to address financial stability concerns in the face of volatile capital flows. In particular, researchers have investigated the pros and cons of taxes on foreign debt, interpreted as economy-wide capital controls, to address the consequences of pecuniary externalities arising from occasionally binding collateral constraints.

The normative analysis of capital controls motivated by a financial stability concern is based

\footnotetext{
${ }^{1}$ See Erten, Korinek, and Ocampo (forthcoming) and Engel (2016) for surveys of the literature on capital controls more broadly defined as CFMs and macroprudential policies.
} 
on variants of a common theoretical framework, with occasionally binding leverage or collateral constraints, proposed and quantitatively investigated by Mendoza (2002) and Mendoza (2010). With occasionally binding leverage constraints, financial crises are endogenous, nested in regular business cycles, identified as rare events in which capital flows come to a sudden stop and output drops more than in a typical recession. When a small negative shock hits the economy, if leverage is high enough, the constraint can bind. A binding leverage constraint amplifies the effects of the triggering shock through fire sales dynamics, and debt deflation spirals driven by declining collateral valuations as in Fisher (1933). Because this modeling environment nests both crisis events and regular business cycles, it is a particularly well-suited laboratory to study the role of crisis-prevention policies, called macro-prudential policies in the literature. ${ }^{2}$ These are policies that are implemented in normal times to contain the frequency and the severity of amplification and fire-sale dynamics in crisis times. ${ }^{3}$

With occasionally binding constraints, atomistic private agents that do not internalize the effect of their decisions on the aggregate borrowing limit give rise to pecuniary externalities and inefficient resource allocation. Pecuniary externalities can arise through redistributive or allocative mechanisms induced by the impact of individual decisions on the market value of the collateral (Dávila and Korinek (2018)). To keep the exposition simple and conserve space, however, in what follows, we focus only on pecuniary externalities working through the allocative effects induced by the presence of a relative price in the specification of the borrowing constraint. $^{4}$

The atomistic behavior of private agents is generally immaterial (and hence the pecuniary nature of the externality). However, when the collateral constraint binds, as Korinek (2007) showed, the individual borrowing decision has an external effect on the relative market price of collateral and thus also on the aggregate resource allocation in the competitive equilibrium of the economy because the collateral value determines borrowing and hence expenditure. ${ }^{5}$ In this environment, a social planner who faces the same borrowing constraint as the private agents

\footnotetext{
${ }^{2}$ The term "macroprudential" is used in analogy with the microeconomic prudential regulations traditionally applied to banks.

${ }^{3}$ See Bordo and Jeanne (2002) for an early formulation and analysis of this problem in a simplified version of Kiyotaki and Moore (1997).

${ }^{4}$ See Caballero and Krishnamurthy (2003), Caballero and Lorenzoni (2014) and Lorenzoni (2008) for examples of pecuniary externalities working through redistributive effects. See Erten et al. (forthcoming) for a survey of the theoretical literature on pecuniary externalities working through both mechanisms in the context of a simple reduced-form model.

${ }^{5}$ More generally, pecuniary externalities are consequential for the resource allocation, and the equilibrium is inefficient, if markets are incomplete, there is imperfect information, and there are multiple goods, thus failing to meet the conditions for the first welfare theorem — see for instance Greenwald and Stiglitz (1986) and Geanakoplos and Polemarchakis (1986).
} 
(i.e., a constrained social planner, or SP for brevity) but takes into account the consequences of her choices on the market value of collateral would generally achieve less volatility and financial amplification relative to a competitive equilibrium (CE). Moreover, in certain model setups, the social planner chooses to restrict borrowing ex-ante relative to the private agents. As a result, borrowing in the CE can be inefficiently larger than in the SP, and the economy displays "overborrowing", which is quantified by comparing savings in the two allocations. 6

In models with occasionally binding constraints, however, overborrowing is neither necessary nor sufficient for the inefficiency of the decentralized equilibrium. ${ }^{7}$ Similarly, as Dávila and Korinek (2018) point out, amplification and fire sales dynamics too are neither sufficient nor necessary for the inefficiency of the competitive equilibrium. Indeed, excess amplification and fire sales can also happen with underborrowing - e.g., Benigno et al. (2013). Moreover, financial crises and amplification also feature the SP but, compared with the CE, they are smaller and less frequent.

In an endowment economy version of the model in Mendoza (2002), Bianchi (2011) and Korinek (2018) show that there is overborrowing and capital controls can implement the SP allocation. In this sense, capital controls, modeled as distortionary taxes on external debt rebated with lump-sum transfers, can be desirable for financial stability purposes from the perspective of the pecuniary externality literature. Consider, for instance, the infinite horizon model of Bianchi (2011). This is a small open economy with two types of goods, tradables and nontradables, and an international borrowing constraint that depends on the relative price of nontradables, typically interpreted as the real exchange rate. Bianchi (2011) shows that, in this economy, under certain parameter restrictions, the competitive equilibrium always entails overborrowing, and that a prudential tax on debt can support the SP allocation as a decentralized equilibrium. The capital control policy that decentralizes the SP allocation is a small state-contingent tax when the constraint is not binding, but expected to bind in the future with positive probability, and otherwise equal to zero. ${ }^{8}$ Capital control policy reduces the frequency and severity of financial crises in the model. Consequently, this policy is welfare improving despite introducing a tax distortion in the economy. However, as Mendoza (2010) and Schmitt-Grohé and Uribe (2016a) noted, in this class of models, the welfare differences between the CE and SP are very

\footnotetext{
${ }^{6}$ See Uribe (2006) for an early discussion of this concept, distinguishing between individual and aggregate specifications of the borrowing constraint.

${ }^{7}$ See, for instance, Benigno, Chen, Otrok, Rebucci, and Young (2010, 2013), Davila, Hong, Krusell, and Ríos-Rull (2012), Schmitt-Grohé and Uribe (2016b).

${ }^{8}$ Note that the tax is zero also when the constraint binds. This is because of two reasons. First, in this endowment economy, the SP and CE allocations coincide when the constraint binds or it does not bind and is not expected to bind in the future. Crises, therefore, are efficient events in this setup, while the run-up to the crisis is not. Second, the tax on debt cannot affect the borrowing constraint when it binds.
} 
small, typically in the order of $0.1 \%$ permanent increase in annual consumption. The welfare gains become even smaller when the model is calibrated to typical emerging market economies data like Mexico, which have lower income volatility and more patience than the calibrated value of these parameters for Argentina (see Benigno et al. (2010)).

Jeanne and Korinek (2018) and Bianchi and Mendoza (2018) analyze models in which domestic assets rather than income are pledged as collateral for borrowing and focus on macroprudential policies rather than capital controls. Thus, the pecuniary externality arises because private agents fail to internalize the effect of their decisions on a domestic asset price entering the collateral constraint, rather than a relative good price. Specifying the borrowing constraint as a function of an asset price introduces time-consistency considerations, which enrich the policy analysis but also add significant computational complexity. However, the main policy implications of the analysis are similar to those of Bianchi (2011) and Korinek (2018).

In a series of papers, Benigno, Chen, Otrok, Rebucci, and Young (2010, 2012, 2013, 2019a) study the effects of pecuniary externalities and the desirability of alternative ex-ante and expost policies to remedy their consequences, based on the production model of Mendoza (2002). They show that, with a production margin that affects the collateral value in the borrowing constraint, capital controls alone cannot restore constrained efficiency and are generally suboptimal policy instruments. ${ }^{9}$ For example, the benchmark production economy of Benigno et al. (2013), calibrated to Mexico, always underborrows. In that context, they also show that imposing a fixed one percent tax on borrowing in "tranquil times" is welfare-reducing, despite the fact that it reduces the probability of a crisis to zero. This illustrates that a lower probability of a financial crisis is not necessarily associated with higher welfare in this class of models, and might be a misleading indicator of the desirability of capital controls policy in empirical studies. More generally, Benigno et al. (2019a) show that, in the same production economy of Benigno et al. (2013) and Mendoza (2002), capital controls are not necessary to implement the SP allocation.

Benigno et al. (2013) also show that, with endogenous production affecting the borrowing constraint, the behavior of the economy during normal times depends crucially on how the economy is expected to behave during crisis times. Therefore, the desirability of ex-ante prudential policies must depend on the set of ex-post tools available in crisis times. For example, an effective bailout policy, not only can mitigate crisis severity, but can also reduce the social value of

\footnotetext{
${ }^{9} \mathrm{Bianchi}$ (2011) reports a robustness exercise extending his model to production. However, this is a production structure in which the only variable input is an inelastically supplied and exogenously priced imported intermediate good, and the planner is not allowed to chose it, making the production economy isomorphic to the endowment case. Bianchi and Mendoza (2018) also have production. The wage bill, however, does not enter the specification of the working capital constraint, and the production margin becomes irrelevant for the solution of Ramsey planner problem they study.
} 
precautionary saving in tranquil times, and hence the desirability of any prudential intervention, including capital controls. Of course, in reality, there are constraints on crisis resolution policies that introduce additional distortions. These considerations range from issues of effectiveness of crisis resolution tools to availability of financing and moral hazard induced by the insurance nature of ex-post interventions such as bailout policies (e.g., Bianchi (2016)). The point here is that the interaction between ex-post and ex-ante interventions is critical for the optimal policy design in this class of models.

For example, Benigno et al. (2016) compare capital controls with the exchange rate policy in the same endowment economy analyzed by Bianchi (2011). They find that, when managing the exchange rate is costless, there is no need to use capital controls, as exchange rate policy can remove the borrowing constraint altogether. Interventions on the real exchange rate through taxes (or subsidies) on consumption financed (or rebated) with lump-sum transfers (i.e., fiscal devaluations or appreciations) dominate capital controls because they can affect the borrowing constraint when it binds, while capital controls cannot. However, if managing the exchange rate entails an efficiency loss stemming from the consequence of its distortionary financing on other margins, capital controls policy must be part of the optimal policy mix. In this case, the optimal mix combines prudential capital controls in tranquil times with exchange rate appreciation in crisis times. Importantly, in this more realistic case, both instruments are applied less intensively than when used as the sole tool of intervention, showing that they complement each other. Interestingly, the optimal policy mix is associated with more borrowing, fewer and less severe financial crises, and much higher welfare than with capital controls alone. The planner achieves these outcomes by allocating total consumption across sectors differently than the private sector, thus, illustrating that the sector allocation of resources matter more than the total quantity borrowed by the economy; a result that is consistent with the policy adage that the sector allocation of the borrowed resources is more critical than the total amount of borrowing.

Similarly, Jeanne and Korinek (forthcoming) analyze the interaction of ex-ante and ex-post interventions in a three-period economy with pecuniary externalities. In their set up, ex-post interventions are effective in reducing the cost of crises but generate moral hazard. Corrective ex-ante policy action is therefore needed to contain it, and the optimal policy mix balances these two forces. Like in Benigno et al. (2016), the optimal policy requires a combination of both exante and ex-post interventions. However, in the setup of Jeanne and Korinek (forthcoming), in which the instrument that can be used ex-post cannot be used ex-ante and vice-versa, ex-ante and ex-post interventions are substitutes rather than complements.

Korinek and Sandri (2016) compare capital controls with macroprudential policy. They set up a model with pecuniary externalities in which both types of policy can play a role. The model 
has both a domestic and an international lender. The difference between the two instruments is that macroprudential policy restricts borrowing by domestic agents independently of whether the credit is provided by the domestic or the foreign lender. In contrast, capital controls restrict only borrowing from the international lender. When the pecuniary externality arises from the presence of the real exchange rate in the collateral constraint, both macroprudential policy and capital controls play a role, since they help curtail credit to domestic borrowers and increase saving by domestic savers. In this case, the pecuniary externality is affected by the net worth of both domestic borrowers and savers, and two policy instruments are needed since the contribution of borrowers and savers to the externality differs. However, when the pecuniary externality arises from the presence of a domestic asset price in the borrowing constraint, there is no role for capital controls to play, and only macroprudential policy remains effective. This is because only the net worth of domestic borrowers matter in this case.

Bengui and Bianchi (2019) emphasize that capital controls and macroprudential policies are constrained by imperfect enforcement, possibly due to shadow banking, regulatory arbitrage, or other circumvention strategies and means. They show that introducing leakages in the typical pecuniary externality analysis undermines the effectiveness of macroprudential taxes, even though interventions designed taking this into account can still mitigate vulnerability to financial crises.

Ma (2020) studies the effects of capital controls in an endogenous growth model with a borrowing constraint and pecuniary externalities. In normal periods, when the borrowing constraint is slack, the growth rate is at its efficient level since private agents can borrow freely to finance their expenditure plans. During crisis times, however, the growth rate falls since expenditure plans are financially constrained. By introducing endogenous growth in an otherwise standard open economy model with occasionally binding borrowing constraints, this model can match the persistent output loss typically associated with financial crises. Moreover, in the model, there is a trade-off between cyclical and trend consumption growth. Capital controls can smooth cyclical growth at the cost of lowering trend growth. Quantitatively, however, the trend growth cost is small, with an average annual output growth decline of $0.01 \%$, while the benefit in terms of smoother cyclical consumption is more sizable with a reduction of the crisis probability of two-thirds. As a result, on net, the optimal capital control policy, in this economy, generates small welfare gains equivalent to a $0.06 \%$ of a permanent increase in annual consumption, comparable to the gains reported in the extant literature. The optimal capital controls can have a larger impact on growth and welfare if there is also a growth externality (such as learning by doing) in the model in addition to the pecuniary externality.

Ma and Wei (2019) consider the quality of domestic institutions. They argue that the level of 
institution quality determines the capital structure of a country, and hence also its vulnerability to financial crises. A country with a relatively low level of institutional quality finds it harder to issue equity-like securities and has to rely on debt-like securities, which results in a higher probability of a financial crisis. In this case, capital controls can help countries to reduce excess volatility and amplification in the face of volatile capital flows. However, when the level of institutional quality is high enough, countries can rely on equity financing to avoid costly financial crises. In this case, there is no role for capital controls, consistent with the fact that virtually no advanced economy uses capital controls for financial stability purposes - e.g., Klein (2012) and Fernández et al. (2015).

\section{Capital Controls and Aggregate Demand Externalities}

A second new rationale for the adoption of capital controls is the presence of aggregate demand externalities, a notion ultimately dating back to Keynes. The key friction in this type of model is a price or wage rigidity, which implies that the economy is demand-driven, combined with a constraint on the optimal use of monetary policy, such as a liquidity trap or a fixed exchange rate. In these economies, private agents are too small to internalize the aggregate demand effects of their decisions. As a result, they may boost aggregate demand excessively during the expansionary phase of the cycle, which makes the economy relatively more vulnerable during the contractionary phase. If during a boom, monetary policy cannot address the distortions induced by relative price rigidity, prudential interventions in financial markets become desirable to manage the expansion to reduce the cost of the contraction.

Farhi and Werning (2016) provide a general theory of prudential interventions in financial markets, including capital controls, justified by the presence of aggregate demand externalities. They show that the competitive equilibrium of a heterogeneous-agent economy with nominal stickiness is generally inefficient when the monetary (or fiscal) policy is subject to constraints that prevent it from achieving the first best, like in relatively simple benchmark closed and open-economy New Keynesian models. The source of nominal rigidity can be either in the good or the labor market. The constraint on monetary policy can arise from a policy choice, such as a fixed exchange rate regime (e.g., Schmitt-Grohé and Uribe (2016a)), or a more natural limitation such as the zero lower bound on nominal interest rates (e.g., Korinek and Simsek (2016)). The result is that the economy cannot fully adjust to shocks using monetary policy alone. In this environment, there can be a clear-cut case for capital control policy to correct the

aggregate demand externality, even abstracting from pecuniary externalities. However, capital controls are not the only tool that can address the inefficiency as other interventions in financial 
markets can complement monetary policy, such as macroprudential policy.

Importantly, the framework proposed by Farhi and Werning (2016) can be used to analyze both the aggregate demand externality that they identify and the pecuniary externality that we discussed in the previous section under incomplete markets. ${ }^{10}$ Moreover, they characterize optimal macroprudential interventions in financial markets as a function of sufficient statistics, such as marginal propensities to spend, elasticities of substitution, and wedges that can, in principle, be backed up from the data to calibrate the policy interventions.

Schmitt-Grohé and Uribe (2016a) studied the optimal use of capital controls to address a demand externality, even though they do not label it as such and focus on its overborrowing implications. The model is a small open economy with a fixed exchange rate and a downward nominal wage rigidity that induces disequilibrium in the labor market in response to contractionary shocks. In their model, the aggregate demand externality arises from the joint presence of these two constraints and free capital mobility. As a result, during good times, private agents push up the nominal wage and borrow excessively. When bad times arrive, there is inefficiently high and persistent demand-driven unemployment. Prudential capital controls are beneficial here because they can slow down wage growth during expansions to reduce the inefficient unemployment losses during recessions. Note also that, with downward wage rigidity, there is equilibrium unemployment in the crisis phase of the cycle, and the welfare gains from setting optimal capital controls are much larger than in the pecuniary externality literature.

Korinek and Simsek (2016) analyze the case for macroprudential policy in an economic setting with a good price rigidity and a zero-lower bound on interest rates. In this paper, there is a link between deleveraging and the aggregate demand externality. When some agents are forced to cut leverage for exogenous reasons, there will be an inefficient demand drop since the interest rate cannot adjust enough to allow other agents in the economy to pick up the resulting slack in aggregate demand. Macroprudential policy is useful here because it reduces the excessive leverage ex-ante, the economy becomes less likely to run into the liquidity trap, and the consequences of the liquidity trap are mitigated. Korinek and Simsek (2016) also show that a contractionary monetary policy is inferior to a macroprudential policy intervention in addressing the excessive leverage ex-ante. The reason is that monetary policy, in this setting, reduces the net worth of borrowers, thereby strengthening their need to borrow external resources.

The broad message of this literature is fairly general and holds whenever a stabilization policy cannot perfectly keep aggregate demand in line with the efficient level of production. The result does not even require an explicit constraint on the monetary policy instrument; for

\footnotetext{
${ }^{10}$ Indeed, Section 5 of Farhi and Werning (2016) provides specific examples under floating or fixed exchange rates, complete or incomplete markets, with a detailed discussion of the mapping of the particular set up to the general model.
} 
example, having multiple sectors or having both good and labor markets nominal rigidity could be enough. As a consequence, several other contributions in the new literature on capital controls could be folded under the broad umbrella of "aggregate demand externality," even though most of them were developed without explicit reference to this framework. Nonetheless, for the sake of exposition, in the rest of this section, we review separately contributions that revisited the role of capital controls in providing monetary policy independence in the traditional Mundellian sense.

\subsection{Capital Controls and the Trilemma of International Finance}

Assume for the sake of comparison that monetary policy can fully address nominal rigidity and achieve the efficient level of output. Then, it is well known that a country can pursue only two of the following three policy objectives: a fixed exchange rate, free capital mobility, independent monetary policy from the rest of the world - the so-called "trilemma" of international finance. According to this traditional Mundellian view, a country committed to free capital mobility must choose between autonomy in setting its monetary policy optimally and exchange rate stability. In other words, when monetary policy can achieve the first best, capital controls are redundant under flexible exchange rates. Under fixed exchange rates, instead, capital controls are necessary to allow domestic monetary policy to diverge from foreign policy.

The traditional view was challenged on empirical grounds for being too optimistic by Rey (2013), who argued that countries, in fact, have to choose between monetary policy autonomy and capital mobility, even if they have flexible exchange rates. This is because capital flows comove very strongly across countries and asset classes, and the so-called "global financial cycle" dwarfs any attempt to insulate individual open economies with domestic stabilization policies. According to this alternative view, all economies except the ones issuing anchor currencies need to control capital flows or use macroprudential policy to secure any degree of monetary policy independence; the trilemma of international finance is, in effect, only a "dilemma" according to this alternative view.

Farhi and Werning (2014) formalize this argument in the context of a specific model nested in the general framework of Farhi and Werning (2016). They analyze the optimal use of capital controls in a standard open-economy New Keynesian framework with nominal rigidity. In particular, they study the economic effects of a risk premium shock, assuming alternative exchange rate regimes and price-setting behaviors. The model is a small open economy with nominal rigidities in which monetary policy cannot achieve first best because the financial markets are incomplete. Consistent with the traditional view, they find that the exchange rate regime matters and a flexible exchange rate does allow for a degree of monetary policy independence. 
However, they also find that capital controls are still desirable, even when the exchange rate is floating, consistent with the "dilemma" view. Capital controls are beneficial in their set up because they can help the external adjustment to the risk premium shock by affecting the terms of trade. Thus, capital controls can complement a flexible exchange rate in this setup.

Chang, Liu, and Spiegel (2015) study the effect of capital controls policy on optimal monetary policy in a DSGE model of the Chinese economy. In their set up, capital controls prevent households from achieving full risk-sharing and creating a wedge between holding domestic and foreign assets. The government has to accumulate foreign reserves to keep the exchange rate fixed. Such intervention comes at the cost of the difference between domestic and foreign interest rates. Thus, there is a trade-off between costly sterilization of reserve accumulation and the benefits of domestic price stability. Chang, Liu, and Spiegel (2015) quantify this trade-off by looking at the impulse response to foreign interest and demand shocks. They find that both capital account liberalization and exchange rate flexibility can generate some welfare gains by ameliorating the policy trade-off faced by the policymaker. However, they also find that adopting a more flexible exchange rate regime generates larger welfare gains than just lowering capital controls, suggesting that the former is a more effective tool than the latter at insulating the economy from external shocks.

\section{Capital Controls with both Pecuniary and Demand Exter- nalities}

A few papers focused on the joint use of optimal capital controls and monetary or exchange rate policy in the presence of both pecuniary and demand externalities. For example, Fornaro (2015) studies alternative exchange rate policy rules in an economy with downward wage rigidity and a pecuniary externality arising from a collateral constraint defined on household landholdings. He finds that a flexible exchange rate regime is preferable to a fixed one. During a financial crisis, exchange rate flexibility has a positive impact on welfare because the stimulus provided by the depreciation by lowering the real wage supports output, employment, and land prices, and hence the value of collateral and access to the international credit markets.

Similarly, Ottonello (2015), introduces pecuniary externalities arising from a collateral constraint defined on the real exchange rate, as in Benigno et al. (2013), into the framework of Schmitt-Grohé and Uribe (2016a). In his model, during the crash, the exchange rate policy must trade-off relaxing the collateral constraint when it binds with containing unemployment. The exchange-rate depreciation necessary to achieve full employment in the presence of down- 
ward wage rigidity would further tighten the binding borrowing constraint during crisis times. In the quantitative analysis of this trade-off, the optimal policy favors more depreciation during crisis times since the welfare cost stemming from unemployment is larger than the cost of the pecuniary externality. In this setup, capital controls are welfare improving as they help contain the size of the crash and hence can ameliorate the trade-off between monetary and financial stability.

Benigno, Chen, Otrok, Rebucci, and Young (2011) set up a three-period economy with both a nominal rigidity and a pecuniary externality arising from a collateral constraint that depends on both the nominal exchange rate and the domestic value of equity. Unlike in Korinek and Simsek (2016), the monetary policy here is not constrained by the liquidity trap, and the exchange rate is floating freely. Benigno et al. (2011) illustrate analytically that, in this setup, when the constraint does not bind, leaning against the wind with the monetary policy interest rate and a tax on debt work essentially in the same way. As a result, prudential capital controls provide tiny welfare gains relative to monetary policy used alone, even though monetary policy alone cannot achieve the first best.

Cesa-Bianchi and Rebucci (2017) propose a model that features both an interest rate rigidity in the banking system, as a way to give rise to a macroeconomic stabilization motive, and a pecuniary externality that provides a financial stability motive as we discussed above. The paper then analyzes the interaction between monetary and macro-prudential policy or capital controls. They show that adding interest rate rigidity to the pecuniary externality increases the probability of a financial crisis in response to a contractionary aggregate demand shock to the economy, while it can act as an automatic macro-prudential stabilizer in response to an expansionary shock. Moreover, when the interest rate is the only available instrument, monetary policy faces a trade-off between macroeconomic and financial stability. Only with a second instrument, such as a capital control or reserve requirement on domestic banks, efficiency in the economy can be restored when both frictions are at work.

Monetary policy procyclicality is an important feature of emerging market economies (e.g., Kaminsky et al. (2005)). Coulibaly (2018) proposes a theory of monetary procyclicality in a model in which access to foreign financing depends on the real exchange rate via non-tradable income used as collateral and the government lacks commitment. Discretionary monetary policy is procyclical in this set up to mitigate balance sheet effects originating from exchange rate depreciation during sudden stops. In this context, committing to an inflation targeting regime increases welfare by reducing the frequency of financial crises, despite making crises more severe. Capital controls support a less procyclical discretionary monetary policy and hence bring about higher welfare relative to inflation targeting alone by reducing both the frequency and the 
severity of crises.

In a similar vein, Davis and Presno (2017) study the extent to which capital controls can support monetary policy autonomy in a country with a floating currency, nominal rigidities, and collateral constraints. Exogenous changes in capital flows lead to volatility in asset prices and credit supply. A central bank with the interest rate as its only instrument finds it optimal to use it procyclically to stabilize the value of the collateral. Capital account restrictions can ameliorate this trade-off, especially in the face of shocks to the foreign interest rate.

Devereux and Yu (2017) and Devereux, Young, and Yu (2018) study the optimal policy under both discretion and commitment in an infinite horizon model with both a nominal rigidity (either in the good or the labor market) and a pecuniary externality arising from a collateral constraint defined on the domestic currency value of capital. Devereux and Yu (2017) find that floating the exchange rate is superior to pegging it, with the welfare gains arising from states of the world in which the collateral constraint is binding and depreciations support aggregate demand. Devereux et al. (2018), however, find that the optimal policy never involves prudential taxes on capital inflow or a departure from price stability, whether or not commitment is available to the policymaker. They show that this negative result on capital controls hinges on the timing of the asset price entering the borrowing constraint. Following Kiyotaki and Moore (1997), Iacoviello (2005) and Liu et al. (2013), they specify a collateral constraint that depends on the expectation of the future asset price, rather than on the current price, as for instance Bianchi and Mendoza (2018) or Jeanne and Korinek (2018). Then, they show that, when the current rather than the future asset price enters the borrowing constraint, there is a case for prudential taxes on inflows and subsidies during a crisis. Similarly, Benigno et al. (2016) show that if the borrowing constraint is defined in terms of net rather than gross income, the relative properties of capital controls and exchange rate policy are turned around. An important lesson of these analyses, therefore, is that the details of the specification of the financial friction matter for the result of the normative analysis and the optimal policy design.

\section{Capital Controls and Terms of Trade Manipulation}

A third new motive for the use of capital controls could be the desire to affect a country's terms of trade. Terms of trade manipulation can be intratemporal, when the price of imports in terms of exports is being manipulated, or intertemporal when the world price of current consumption in term of future consumption is targeted.

Costinot, Lorenzoni, and Werning (2014) study how capital controls might affect the intertemporal terms of trade. In an infinite-horizon, endowment, two-country world economy, 
they argue that one country may have the incentive to use capital controls to manipulate the world interest rate in its favor. In particular, a country may want to tax capital inflows or subsidize capital outflows when its income grows faster than the rest of the world. The intuition is as follows. When the home country grows faster than the rest of the world between any two periods, it has a larger future trade surplus (or smaller deficit) than the present one. Thus, the home country has an incentive to lower the world interest rate between today and tomorrow by lowering current consumption and hence running a smaller current trade deficit (or larger trade surplus). In this case, a tax on capital inflows or a subsidy to outflows in the current period is desirable as it increases current savings and can shift consumption from today to tomorrow. The quantitative differences in the consumption allocation and welfare gain, however, are small. In an example with CRRA preferences and aggregate fluctuations, Costinot et al. (2014) find that the optimal capital control tax is less than 1 percent and has a small impact on consumption and welfare, with an order of magnitude similar to the gains from financial integration reported in the literature, usually considered very small.

As Obstfeld and Rogoff (1996) noted, the use of capital controls for terms of trade manipulation is similar to the optimal tariff argument in trade theory. The optimal tariff interpretation says that the home country has an incentive to tax capital inflows (outflows) when borrowing and the trade balance is in deficit (lending and the trade balance is in surplus) to decrease (increase) world interest rate in its favor. Unlike the analysis of capital control policy in a twoperiod model of Obstfeld and Rogoff (1996), where the use of capital controls depends on the country's status as a borrower or lender, Costinot et al. (2014) emphasize the importance of the contemporaneous rate of growth compared to its trading partners in determining the use of capital controls. Their key insight is that capital controls should not be set based on the absolute desire to alter the intertemporal prices of goods in a given period, but rather based on the relative strength of this desire between two periods.

De Paoli and Lipinska (2012) focus on how capital controls can affect the intratemporal terms of trade. When output supply falls because of a negative productivity shock, a planner that maximizes the welfare of the domestic economy wants to tax foreign borrowing to support the consumption of domestic goods, and thereby improve the terms of trade. The terms of trade improvement permits to lower labor effort and, via this channel, increase welfare in a counter-cyclical fashion.

The terms of trade manipulation motive for capital controls is most suitable to explain cases of countries that have pricing power in international markets because of their size. For instance, China's capital controls have often been interpreted as aimed at achieving a certain level of competitiveness in recent years but could be reinterpreted in this framework. The consequence 
of using capital controls in this manner is to generate spillover effects on other countries, a typical problem of "beggar-thy-neighbor" policies. As a result, countries on the receiving end of such spillovers also have an incentive to impose capital controls as a response, possibly leading to coordination issues and dynamics sometimes referred to as "currency wars" in the policy debate.

A few theoretical contributions focused on the welfare costs of capital control competition or the gains from cooperation. For example, Heathcote and Perri (2016) use a standard twocountry international business cycle model with incomplete markets to evaluate the welfare effects of capital controls competition. They conclude that the welfare impacts are ambiguous and depend on the specifics of the calibration and and the properties of the country-specific shock processes. Giordani, Ruta, Weisfeld, and Zhu (2017) also focus on a coordination problem among the countries imposing controls on capital inflows. They show that inflow restrictions deflect international capital flows to other countries and that these spillovers may lead to a policy response in the receiving countries.

On the other hand, Jeanne (2018) provides a tractable model of a global economy with downward nominal rigidity and a liquidity trap to analyze the welfare cost of currency and trade wars. He finds that the welfare cost of the trade wars is higher than that of the currency wars, suggesting that the case for capital account policy coordination based on spillover effects need to be made with caution. As a benchmark, Korinek (2016) spells out three conditions under which there is no case for policy coordination even in a world with spillover effects. The logic is similar to the one in the first welfare theorem. The global market outcome is Pareto efficient as long as (i) policymakers act competitively in the international market; (ii) policymakers have sufficient external policy instruments; (iii) and international markets are free of imperfections. These are strict conditions often violated in practice suggesting that it is more likely than not that coordination would be beneficial. Nevertheless, they provide a useful benchmark for the analysis of specific inefficiencies that can be addressed by policy coordination.

\section{Post-GFC Empirical Evidence}

The post-GFC literature on capital controls also includes empirical contributions. The new empirical literature has evolved along two lines: one focused on constructing metrics to describe capital control and macroprudential policies and to characterize how countries use these instruments; the other concerned with the more traditional question of capital control effectiveness relative to stated objectives. Note here that, while the first stream of empirical research is grounded more firmly on the new theories, the contributions in the second stream continued to 
benchmark the analysis to observable variables identified in the policy debate like capital flows, the level of the exchange rate, credit growth and leverage, as well as composition of capital flows and likelihood of financial distress in partial equilibrium setups.

\subsection{Characterizing Capital Control Policy}

Most of the empirical work on measuring capital controls is based on the IMF's Annual Report on Exchange Arrangements and Exchange Restrictions (AREAER), which describes the set of de jure restrictions in place in each of the IMF member countries on a wide range of international transactions.

For example, building on the independent AREAER-based classification work of Schindler (2009), Klein (2012) and Fernández, Rebucci, and Uribe (2015), Fernández, Klein, Rebucci, Schindler, and Uribe (2016) constructed a set of capital control indexes for 10 asset categories in 100 countries during the 1995-2017 period, covering both inflows and outflows. ${ }^{11}$ The coding algorithm uses dummy variables to classify whether or not restrictions on a particular category of cross-border transactions are in place in any given country-year. The authors then constructed a set of indexes on the extensive margin of capital control policy by adding up the dummy variables by asset classes, by all controls on inflows or outflows. ${ }^{12}$

Klein (2012) classifies countries based on their use of capital controls as "open," "walls" and "gates" depending on whether capital controls are never used, are applied on a broad range of assets or liabilities and always kept on, or imposed on selected transactions temporarily. He then documents that most advanced economies belong to the first group, while many lowincome countries are in the second. Only some middle-income countries use capital controls intermittently, on select asset categories, possibly consistent with some of the theories discussed in the previous sections.

Fernández, Rebucci, and Uribe (2015) describe actual capital control policy in a sample of 78 countries over the period 1995-2011 and ask whether countries have used these tools

\footnotetext{
${ }^{11}$ The data set covers equities, bonds with an original maturity of more than one year, money market instruments, collective investment securities such as mutual funds and investment trusts, derivatives, commercial credits, financial credits, guarantees, sureties and financial back-up facilities, direct investment, and real estate transactions. It is periodically updated and can be found at http://www. columbia. edu/ mu2166/fkrsu/.

${ }^{12}$ Two other annual indexes of capital account openness with broad country coverage are the Dennis (1997) (subsequently extended and updated by Dennis and Toyoda (2008)) and the Chinn and Ito (2006) indexes. The Chin and Ito and the Quinn indexes have a much longer time coverage than the indexes constructed by Fernández et al. (2016), starting in 1950 and 1970, respectively. The Quinn Index also captures the intensive margin of capital control policy, albeit imperfectly, while the Chin and Ito index also covers the largest sample of lowincome countries available. Both indexes, however, are highly aggregated by asset class and do not distinguish between controls on inflows and outflows, which is crucial to relate these empirical measures to their theoretical counterparts.
} 
countercyclically, as suggested by several of the theoretical contributions reviewed in this paper. They find that, in general, there is no evidence of countercyclical use of capital controls, a conclusion independently reached also by Eichengreen and Rose (2014). As these authors point out, this could be a case of "theory ahead of policy practice", or alternatively suggests that the theories reviewed above may not be capturing relevant economic or political factors that determine the cyclical properties of optimal capital controls, thus pointing to the importance to study capital controls with additional distortions other than pecuniary or demand externalities. ${ }^{13}$

By comparison, based on a novel quarterly dataset for 52 countries for the period 19702011, Federico, Vegh, and Vuletin (2014) analyze the use and cyclical properties of reserve requirements, which is a typical macroprudential policy instrument often considered in DSGE models, and whether in practice this instrument substitutes or complements monetary policy. They find that about $2 / 3$ of developing countries have used reserve requirements as a macroeconomic stabilization tool compared to just $1 / 3$ of industrial countries (with no industrial country since 2004). Moreover, most developing countries that rely on this tool use it countercyclically. Given that in many developing countries, monetary policy is procyclical, reserve requirements appear to have substituted for monetary policy as a countercyclical tool. Federico et al. (2014) interpret the latter finding as reflecting the need for many emerging markets to raise interest rates in bad times to defend the currency and not raise or lower the interest rate in good times to prevent further currency appreciation. Under these circumstances, reserve requirements represent a second instrument that substitutes for monetary policy.

Similarly, based on IMF survey data, Cerutti, Claessens, and Laeven (2017) document the use of macroprudential policies in 119 countries over the 2000-2013 period, covering many instruments. They find that emerging economies use macroprudential instruments most frequently, especially foreign exchange related ones, while advanced countries use borrower-based tools more. Akinci and Olmstead-Rumsey (2018) construct an index of macroprudential policy in 57 advanced and emerging economies covering the period 2000:Q1-2013:Q4, with tightening and easing measures recorded separately. They show that macroprudential policies have been used far more actively after the GFC in both sets of countries, usually changed in tandem with reserve requirements, capital controls, and monetary policy.

Overall, this evidence suggests that countries have adopted macroprudential policies consistent with the new theoretical literature. However, they might be reluctant to discriminate

\footnotetext{
${ }^{13}$ As Erten et al. (forthcoming) note, a certain degree of time-invariant capital account "closure," as observed in many low-income countries (i.e. the wall cases on Klein (2012)), can also have prudential benefits theoretically. The problem with this approach to prudential capital control policy is that, if fixed capital controls are imposed suboptimally, they can reduce welfare even if they eliminate financial crises. See Benigno et al. (2013) for an example in which the probability of a crisis goes to zero with a fixed tax on net flows, but welfare declines significantly.
} 
between home and foreign residents for reasons that are not present in simple models with pecuniary or demand externalities. This is also consistent with the view that imposing capital controls may indicate readiness to adopt investor-unfriendly policies in the future as in the signaling model of Bartolini and Drazen (1997). ${ }^{14}$

\subsection{Capital Control Policy Effectiveness}

The post-GFC crisis cross-country and country-specific evidence is broadly in line with the precrisis one. The theories of capital controls that provide alternative rationales for the adoption of controls on capital flows, however, provide new benchmarks against which to evaluate their benefits and costs. As stated in the introduction, one way to summarize the consensus before the GFC is to say that capital controls may have some effects on the currency or maturity composition of the inflows, but limited ability to affect total flows and are generally not effective at preventing excessive appreciations or depreciation of the exchange rate. They also tend to raise the cost of capital for smaller borrowers and have leakages and side effects. This was brought out most clearly by the detailed case studies based on the more prominent examples of countries that used capital controls, including Chile (e.g., Edwards (2004), De Gregorio et al. (2000), and Forbes (2007b)) and Malaysia (e.g., Dornbusch (2002)) in the second half of the 1990s. ${ }^{15}$ In particular, Forbes (2007b) analyzed the effect of the Chilean Encaje, a tax on short-term capital inflows imposed by Chile from 1991 to 1998, on the financing cost of publicly-traded firms and found that smaller firms experienced a significant increase in financing cost during that period. Forbes (2007a) provided a detailed survey of the literature on the microeconomic effects of capital controls, finding that capital controls can generate additional unintended consequences with unexpected costs in addition to increased financing.

Cross-country evidence New cross-country studies tend to find evidence of capital control effectiveness consistent with the new theories, albeit with leakages as stressed by both macroeconomic theory (Bengui and Bianchi (2019)) and microeconomic evidence (Forbes (2007a)). For example, Ostry, Ghosh, Chamon, and Qureshi (2012) show that tighter capital controls and FX-related macroprudential measures are associated with a lower share of foreign exchange denominated lending in total domestic bank credit, and with a lower proportion of debt liabilities

\footnotetext{
${ }^{14}$ Theoretically, Bartolini and Drazen (1997) take capital controls as a signal of future government policies. They show that present lower capital controls point to fewer future controls, which tends to increase investment. They argue that a currently relatively more open capital account signals less reliance on the inflation tax in the future - and more generally looser fiscal constraints - thus stimulating investment. Consistent with this mechanism, Grilli and Milesi-Ferretti (1995) report pre-GFC evidence that controls on capital flows are associated with higher fiscal deficits, inflation, and seigniorage revenue.

${ }^{15}$ For a comparative analysis of these and other case studies, see IMF (2000).
} 
in total liabilities. To the extent to which portfolio debt is associated with a higher probability of a financial crisis, as suggested by the theory, capital controls can enhance financial stability by affecting the external capital structure of a countries' portfolio. Similarly, Bruno, Shim, and Shin (2017) document that capital flow management interventions in the banking sector, are effective in slowing down banking inflows in a sample of 12 Asia-Pacific economies over the period 2004-2013. One issue here is that CFMs are not the same as capital controls, as specified in the theoretical models. CFMs, in fact, include both measures narrowly based on residency criteria and measures based on the currency denomination of the transactions.

Cerutti, Claessens, and Laeven (2017) also report that the use of macroprudential tools is generally associated with lower credit growth, and notably household credit growth. However, these associations are weaker in financially more developed and open economies, and usage is also correlated with higher cross-border borrowing, possibly suggesting leakage and avoidance, consistent with the microeconomic evidence surveyed by Forbes (2007a).

Using a propensity-score matching technique to address endogeneity, Forbes, Fratzscher, and Straub (2015) find that most CFMs do not significantly affect the exchange rate, total flows, monetary policy independence, and volatility. However, the authors also find that these measures can reduce financial vulnerability, consistent with the prediction of the new theories, which suggest that small differences between the constrained efficient and market-determined allocations can have a potentially large impact on the probability of financial crises. The issue here is that richer models with multiple margins, like for instance in Benigno et al. (2013), a lower probability of a financial crisis is not necessarily associated with higher welfare.

Ahnert, Forbes, Friedrich, and Reinhardt (2018) evaluate the effectiveness and unintended consequences of macroprudential foreign exchange regulations, testing the predictions of a simple model of bank and market lending in domestic and foreign currency. They find that foreign currency regulations are effective in reducing borrowing in foreign currency by banks, but have the unintended consequence of simultaneously causing firms to increase their foreign exchange exposure. Similarly, Bacchetta, Cordonier, and Merrouche (2019) analyze the role of capital controls and macroprudential policies in determining the foreign currency exposure of corporate bond issuances in emerging economies. Using firm-level data on corporate bond issuances in 17 EME between 2003 and 2015, they document strong evidence of the global financial cycle at work, with companies more likely to issue bonds in foreign currency when US interest rates are low. Capital controls on bond inflows, however, significantly decrease the likelihood of issuing debt in foreign currency, insulating issuances from low US interest rates. As in Ahnert et al. (2018), macroprudential foreign exchange regulations tend to increase foreign currency issuances of nonfinancial corporates, although this cross-asset spillover effect is reduced 
if macroprudential policies are accompanied by capital controls.

Very few new cross-country studies focus on controls on outflows. Forbes and Klein (2015), using propensity-score matching techniques, estimate how significant reserve sales, currency depreciation, changes in policy interest rates, and increased controls on capital outflows affect real GDP growth, unemployment, and inflation during two periods marked by crises, 1997-2001 and 2007-11. The paper shows that large interest rate hikes and new capital controls can cause a significant decline in GDP growth. In contrast, a sharp currency depreciation may raise GDP growth over time, but only with a significant lag and after an initial contraction.

New case studies One of the most active countries using taxes on capital flows during and after the GFC crisis period was Brazil. The Brazil case is particularly interesting because the Brazilian Imposto Sobre Operacoes Financeiras (IOF), a tax on specific financial instruments applied with varying intensity, very similar to the tax rates in the theoretical models, was used countercyclically since the early 1990s.

Chamon and Garcia (2016) estimate the impact of the IOF tax rate increases since February 2009, after a period in which they had been set to zero during the GFC. The authors report that the tightening cycle they focus on had some success in segmenting Brazilian capital markets from the rest of the global financial system, as measured by the spread between onshore and offshore dollar interest rates or the ADR premium relative to the underlying local stocks. However, the measures adopted from late 2009 to mid-2011 did not translate into significant changes in the exchange rate, suggesting limited success in mitigating exchange rate appreciation pressure. Even though the Brazilian Real sharply depreciated after a tax on the notional amount of derivatives was introduced in mid-2011. The authors suggest that, cumulatively, the measures studied may have depreciated the Brazilian real in the 4-10 percent range. Nevertheless, they also contemplate that this strong response might have been driven by a complementarity with an unexpected easing in monetary policy that occurred at the same time, consistent with the crosscountry evidence reported by Federico et al. (2014) and many of the theoretical contributions reviewed in the first part of the paper.

Consistent with the extant literature on Chile, other studies find that the imposition of controls on inflows after the GFC in Brazil entailed a significant increase in financing costs, as also implied by the new theories. For example, Alfaro, Chari, and Kanczuk (2017) estimate the effect of the IOF on portfolio debt and equity on firm-level stock returns during the period 2008-2013. They document that stock returns fall following capital controls announcements. Moreover, the negative impact is more pronounced for smaller firms, in line with Forbes (2007b). While it is tempting to see these differential costs as a side effect of capital controls policy, if looking through the lenses of the new theories, an increased cost of capital is an intended consequence 
of the policy intervention.

Keller (2018) study whether CFMs imposed on banks to limit their foreign exchange exposure end up inducing firms to borrow more in foreign currency in the case of Columbia. She shows that, indeed, capital controls encourage firms to take on more foreign currency loans. This evidence is clear evidence of leakage and spillover to other transactions, consistent with the cross-country evidence of Ahnert et al. (2018) and Bacchetta et al. (2019), raising questions as to whether controls can narrowly target a specific transaction that is deemed to pose more risk to financial stability as often assumed in the theoretical models. It is unclear, however, from a theoretical standpoint, that shifting foreign exchange rate risk to firms is an undesirable side effect. Firms, in fact, might have access to natural hedges, financial and non-financial hedging techniques, and a shareholding structure and base that, unlike depositors, is capable of bearing financial risk.

Epure, Mihai, Minoiu, and Peydró (2018) investigate whether macroprudential policies affect the level and composition of household credit with granular microdata from Romania. They show that macroprudential interventions can also affect (ex-ante) riskier borrowers and dampen the transmission of external financial conditions to the local household credit cycle. These policy actions also reduce the sensitivity of riskier types of credit when external conditions are loose, and foreign monetary policy rates are low. The effects reported vary by type of intervention, with measures targeting households seemingly more potent than measures targeting banks, thus showing that macroprudential policy can also substitute for capital controls and, above all, that the details of the policy design and implementation matter for the final outcomes.

The problem here, which is common to all country studies reviewed, is that there are no observable measures that net out the intended costs and benefits of capital controls and correlate unambiguously with welfare as evaluated in the theoretical models used to justify capital controls. In other words, while case studies can establish effects and side-effects of capital control policy causally, they remain reduced-form, partial equilibrium's assessments that are not informative on the desirability of the interventions.

Trilemma vs. Dilemma A critical mass of empirical research focused on the trilemma hypothesis. For example, Klein and Shambaugh (2015) consider whether partial capital controls and limited exchange rate flexibility allow for full monetary policy autonomy in the context of a broad cross-section study. They find that partial capital controls do not generally allow for greater monetary control than fully open capital accounts unless the controls are quite extensive. In contrast, a moderate degree of exchange rate flexibility does allow for some degree of monetary autonomy, especially in emerging and developing economies.

Han and Wei (2018) re-examine international transmissions of monetary policy shocks from 
advanced economies to emerging economies. They document a pattern between the trilemma and the dilemma: without capital controls, a flexible exchange rate offers some monetary autonomy when the center country tightens its monetary policy, yet it fails to do so when the center country loosens policy. In contrast, capital controls help to insulate periphery from monetary policy shocks from the center even when the latter lowers its interest rate.

Pasricha, Falagiarda, Bijsterbosch, and Aizenman (2018) built a quarterly indicator for 16 emerging countries of CFM tightening and loosening actions around the time of the GFC, from 2001Q1 to 2012Q4. Tightening and loosening CFM actions are then aggregated by weighting with the share of international assets or liabilities affected by the measure in total assets or liabilities. Pasricha et al. (2018) then focus on the domestic and multilateral effects of these interventions. As far as the domestic effects of capital controls are concerned, they find that increases in capital account openness are associated with reduced monetary policy autonomy and increased exchange rate stability, confirming the constraints of the monetary policy trilemma, and that both gross inflows and outflows rise, while the effect on net capital flows is ambiguous.

Zeev (2017) investigates whether capital controls can help countries mitigating the impact of an international credit shock. Specifically, he focuses on the differential output impulse response of a global credit shock and finds a statistically significant difference between countries at the 75th percentile of the capital inflow control index distribution, relative to countries at the 25 th percentile. Zeev (2017) interprets this difference as evidence of a shock-absorbing capacity of capital controls even if they are not used in a counter-cyclical manner and are always in place like the "walls" of Klein (2012). However, Cesa-Bianchi and Rebucci (2017) shows that, while loan-to-value and foreign exchange denomination limits are associated with lower consumption sensitivity to an international credit supply shock in a broad cross-section of both advanced and emerging insulate, controls on capital inflows are not, except for a few exceptional cases like China. Klein (2012) reach a similar conclusion, reporting no evidence that "gate" countries fare better than others in terms of reduced vulnerability to external shocks.

Related to this, Ma, Rogers, and Zhou (2019) study a specific stock market liberalization episode in China in the mid-2010s, the Shanghai-Hong Kong Stock Connect. The connect program allowed investors based in China, Hong Kong residents, and foreign investors to trade some stocks listed on both markets, through exchange and clearing houses in their home market. Using a difference-in-difference approach, Ma et al. (2019) show that, after the introduction of the program, firm-level investment in China became negatively affected by contractionary US monetary policy shocks, even though equity prices increase and borrowing costs decline. The result suggests that the controls were adequate before their removal under this program, as postulated by the trilemma hypothesis. 
Spillovers The empirical literature find not only evidence of capital control policy spillovers across assets but also across countries, raising important coordination issues. One possible channel is through the portfolio rebalancing of global mutual funds. Consistent with the results from other country studies, Forbes, Fratzscher, Kostka, and Straub (2016) find evidence that capital control policy in Brazil had cross-asset spillovers, with interventions targeting bond inflows affecting the foreign purchase of Brazilian equities. Moreover, Forbes, Fratzscher, Kostka, and Straub (2016) also illustrate that mutual fund managers decreased their portfolio allocations to Brazil and increased their investment in other countries, once Brazil imposed capital controls during the 2008-2013 period, even though the authors acknowledge that other Brazil-specific risk factors might have triggered such reallocation.

Along this line, Pasricha et al. (2018) illustrate that capital inflow restrictions generated significant cross-country spillovers, especially in the post-2008 environment of abundant global liquidity. Furthermore, they also uncover domestic policy responses to foreign capital control changes in countries that are affected by these spillovers. Giordani, Ruta, Weisfeld, and Zhu (2017) evaluate a coordination model empirically using data on inflow restrictions and gross capital inflows for a large sample of developing countries between 1995 and 2009. Like Pasricha et al. (2018), they find evidence that capital controls deflect capital to other countries with similar economic characteristics. However, Giordani et al. (2017) do not report evidence of a policy responses to such spillovers.

\section{Open Research Questions and Further Readings}

Pecuniary and demand externalities provide new and distinct theoretical justifications for the use of capital controls to prevent and manage financial crisis and business cycles, especially in emerging market economies that face tighter financial frictions and more constraints on macroeconomic policy making than advanced economies. Several questions remain open in this new literature that are important areas of ongoing and future research.

First, while only a few countries have adopted the use of capital controls in a countercyclical manner (Fernández et al. (2015) and Eichengreen and Rose (2014)), many have used macroprudential policy tools countercyclically (Federico et al. (2014), Cerutti et al. (2017) and Akinci and Olmstead-Rumsey (2018)). This fact is puzzling for the new capital control theories. One possible explanation is that intervention in foreign exchange markets can achieve similar goals. For example, departing from the observation that foreign exchange intervention is used extensively both before and during financial crises (e.g., Ilzetzki, Reinhart, and Rogoff (2019)), a few 
papers explore the role of this instrument in addressing pecuniary and demand externalities. ${ }^{16}$

Another possibility is that capital controls have additional costs omitted from the simple models reviewed, such as signaling effects, leakages, spillovers, and retaliation risks. For instance, Magud, Spilimbergo, and Werner (forthcoming) show evidence of a strong association in Latin America between the adoption of capital controls and populist policies, such as procyclical fiscal and monetary policy, the imposition of exchange rate restrictions and the adoption of fixed exchange rate arrangements, consistent with the signaling model of Bartolini and Drazen (1997) and previous evidence on populism in Latin America (see Dornbusch and Edwards (1990)). The framework with two distortions of Ma and Wei (2019) is also in line with this view and suggests that adding political economy considerations to the models reviewed is a promising area of future research to explain the gap in the countercyclical usage between macroprudential and capital control policies.

Second, both the theory and evidence reviewed in this paper suggest that capital controls can at best complement exchange rate flexibility, but there is no compelling case that capital control policy can substitute for exchange rate policy. Protecting monetary policy independence is the longest standing and best understood motivation for the use of capital controls, with China being the "case in point." The available evidence suggests that capital controls are necessary to escape the trilemma under fixed exchange rates. However, the case for capital controls based on the dilemma argument under exchange rate flexibility is much weaker, and more research is needed to evaluate this important hypothesis.

There is evidence of a global financial cycle (e.g., Rey (2013) and Cerutti et al. (2017)), which is consequential for consumption and output variability (e.g., Cesa-Bianchi, Ferrero, and Rebucci (2018) and Cesa-Bianchi, Pesaran, and Rebucci (forthcoming)), but the inability of floating exchange rates to provide adequate insulation is not an established fact (see, for instance, Cesa-Bianchi et al. (2015)). The research reviewed in this paper suggests that, if the exchange rate is allowed to work, it can go a long way toward providing monetary policy independence and supporting adjustment to external shocks. However, when nominal rigidities and borrowing constraints in foreign currency interact with frictions on currency invoicing in international trade (e.g., Gopinath and Stein (2018)), the exchange rate can lose its expenditure switching properties at the core of most theoretical models reviewed as in the local currency pricing environment of Devereux and Engel (2003). Under these conditions, capital controls might be the only policy tool left to insulate the economy from external financial shocks and avoid the dilemma. Considering the role of currency invoicing combined with financial con-

\footnotetext{
${ }^{16}$ See, for instance, Cavallino (2019), Fanelli and Straub (forthcoming), Céspedes, Chang, and Velasco (2017) and Cespedes and Chang (2019), Arce et al. (2019), and Benigno, Rebucci, and Yu (2019c).
} 
straints in the international transmission of US monetary policy shocks (e.g., Senay and Sutherland (2015)) thus seems particularly important are of future research. ${ }^{17}$ This also raises the empirical question of whether capital controls are more beneficial in countries with invoicing constraints.

Third, it is challenging to evaluate the costs and benefits of capital control policy empirically. Lots of progress has been made in establishing the causal effects of capital controls. Researchers constructed capital control indexes disaggregated by asset classes, indexes trying to capture the intensive margin, and indexes measuring policy at a quarterly frequency. Researchers also used very rich micro-level datasets on firms and households and developed sophisticated techniques to address endogeneity issues. These efforts led to better measurement and credible identification of the causal effects of capital controls and provided a better understanding of the mechanisms at work.

Nonetheless, the partial equilibrium reduced-form approach predominantly used in the extant empirical literature is not informative on the overall welfare impact of capital control policy. For example, metrics like the probability of a financial crisis and the level of borrowing or its rate of growth are not sufficient statistics for the net benefit or cost of the policy intervention. On the other hand, welfare evaluations in calibrated general equilibrium models in which capital controls are not the only instrument capable of supporting the constrained efficient allocation are particularly fragile (e.g., Benigno et al. (2016)). To address the latter issue, Benigno et al. (2019a) suggest to evaluate the welfare properties of capital control and macroprudential policies by computing Ramsey optimal policy, as for example in Bianchi and Mendoza (2018) and Benigno et al. (2012), rather than seeking policy rules that decentralize the constrained efficient allocation as done in much of the theoretical literature reviewed in this paper. Another route to capital control policy evaluation is horse-racing alternative policies in larger, data-congruent, general equilibrium models with multiple distortions in the spirit of the inflation-targeting literature on monetary policy. A notable new development, in this direction, is the possibility to estimate structural models with occasionally binding collateral constraints as in Bocola (2016) or Benigno, Foerster, Otrok, and Rebucci (2019b).

\section{Concluding Remarks}

A new theoretical literature motivates the use of controls on capital flows to help prevent and manage financial crises and business cycles triggered by real, monetary and financial shocks.

\footnotetext{
${ }^{17}$ An example of research going in this direction is the Integrated Policy Framework of the IMF outlined by Gopinath (2019).
} 
This paper reviewed selected post-Global Financial Crisis theoretical and empirical contributions. A few lessons can be drawn from the review.

Pecuniary and demand externalities provide clear theoretical rationales to consider adopting capital controls. The welfare properties of capital control policy, however, depend on the structure of the economy, the availability of and the interaction with alternative policy instruments and country characteristics, including particularly the exchange rate regime, fiscal policy, and the level of institutional development. Most importantly, capital controls are generally not the only instrument that can do the job. The consequences of pecuniary and demand externalities can be corrected also with other instruments, and some interventions seem to be much more effective than others from a theoretical standpoint. This is also reflected in the empirical work reviewed, which shows that the details of the policy framework matter, including particularly the degree of exchange rate flexibility, whether capital controls are used as "gates" or "walls" and are defined narrowly like in this paper or more broadly as capital flow management measures. It is therefore important to include in the analysis explicit constraints on the use of fiscal, monetary and exchange rate policies, or macroprudential policy, together with the specific frictions that the policy is addressing.

Second, contrary to prevailing consensus, if evaluated through the lenses of the new theories, the empirical literature suggests that capital controls can have the intended effects. In other words, more clearly spelled out theoretical motivations for the use of capital controls and mechanisms through which they can work permit to make sense of the old and new empirical evidence on the causal effects of capital control policy. Nevertheless, assessing empirically in any given context whether or not capital controls are a welfare-enhancing policy tool, and have a unique ability to do so, remains an elusive task. According to the new theories, the effects on total flows need not be large to have significant impacts on crisis probabilities. The empirical literature finds small impact on total flows and significant effects on the likelihood of financial crises. According to the new theories, capital controls can tilt borrowers' capital structure toward longer-term equity-like liabilities, or away from foreign exchange denomination. These effects accompanied by increases in the relative costs of using the financial instruments that policy tries to discourage. The empirical literature confirms that capital controls can alter the composition of country portfolios in these directions. Several empirical studies find that capital controls increase financing costs especially for smaller and more financially constrained firms. It remains unclear whether lower crisis probabilities associated with slower borrowing and higher financing costs, albeit consistent with some of the new theories, amount to a net welfare gain or a loss. The observable variables used in the empirical research in partial equilibrium set ups cannot be mapped into welfare in the theoretical models. Moreover, some 
theoretical analyses show that focusing on the amount of borrowing, the likelihood of crises, or the financing costs per se may be misleading.

Terms of trade manipulation also provides a clear case for the use of capital controls, but the practical relevance of this theoretical motive is less compelling. The logic of this motivation applies to large economies able to affect the world interest rate or their terms of trade. Yet again, we observe that most large advanced economies do not use capital controls (and similarly do not engage in exchange rate intervention). Both theory and evidence suggest that the use of such tools for the purpose of manipulating international relative prices could trigger retaliation and contentious policy coordination issues. 


\section{References}

Ahnert, T., K. Forbes, C. Friedrich, And D. Reinhardt (2018): "Macroprudential FX Regulations: Shifting the Snowbanks of FX Vulnerability?" NBER Working Paper No. 25083.

Akinci, O. And J. Olmstead-Rumsey (2018): "How Effective are Macroprudential Policies? An Empirical Investigation,” Journal of Financial Intermediation, 33, 33-57.

Alfaro, L., A. Chari, And F. KAnCzuK (2017): “The Real Effects of Capital Controls: Firm-level Evidence from a Policy Experiment," Journal of International Economics, 108, 191-210.

ArCE, F., J. Bengui, And J. BiAnchi (2019): “A Macroprudential Theory of Foreign Reserve Accumulation," NBER Working Paper No. 26236.

Bacchetta, P., R. Cordonier, And O. Merrouche (2019): “The Rise in Foreign Currency Bonds: The Role of Capital Controls," manuscript.

Bartolini, L. AND A. Drazen (1997): “Capital-Account Liberalization as a Signal,” American Economic Review, 87, 138.

Bengui, J. And J. BiAnChi (2019): “Macroprudential Policy with Leakages,” Manuscript.

Benigno, G., H. Chen, C. Otrok, A. Rebucci, and E. R. Young (2010): "Revisiting Overborrowing and Its Policy Implications," Analysis and Economic Policies Series, 14.

(2011): "Monetary and Macro-prudential Policies: An Integrated Analysis," Paper prepared for the 2011 IMF ARC Conference.

(2012): “Optimal Policy for Macro-Financial Stability," CEPR Discussion Paper DP9223.

(2013): "Financial Crises and Macro-Prudential Policies," Journal of International Economics, 89, 453-470.

(2016): “Optimal Capital Controls and Real Exchange Rate Policies: A Pecuniary Externality Perspective," Journal of Monetary Economics, 84, 147-165.

26397.

Benigno, G., A. Foerster, C. Otrok, And A. Rebucci (2019b): "Estimating Macroeconomic Models of Financial Crises: An Endogenous Regime Switching Approach," Tech. rep.

Benigno, G., A. Rebucci, And C. Yu (2019c): “Optimal FX Intervention for MacroFinancial Stability," Manuscript. 
BiAnCHI, J. (2011): “Overborrowing and Systemic Externalities in the Business Cycle," American Economic Review, 101, 3400.

- (2016): “Efficient Bailouts?” American Economic Review, 106, 3607-59.

Bianchi, J. And E. G. Mendoza (2018): “Optimal Time-Consistent Macroprudential Policy,” Journal of Political Economy, 126, 588-634.

Bocola, L. (2016): “The Pass-Through of Sovereign Risk," Journal of Political Economy, 124, 879-926.

Bordo, M. D. And O. Jeanne (2002): "Monetary Policy and Asset Prices: Does Benign Neglect Make Sense?” International Finance, 5, 139-164.

Bruno, V., I. ShIM, AND H. S. SHIN (2017): “Comparative Assessment of Macroprudential Policies,” Journal of Financial Stability, 28, 183-202.

Caballero, R. J. And A. Krishnamurthy (2003): "Excessive Dollar Debt: Financial Development and Underinsurance," Journal of Finance, 58, 867-893.

Caballero, R. J. And G. Lorenzoni (2014): "Persistent Appreciations and Overshooting: A Normative Analysis," IMF Economic Review, 62, 1-47.

Cavallino, P. (2019): “Capital Flows and Foreign Exchange Intervention,” American Economic Journal: Macroeconomics, 127-70.

Cerra, V. And S. C. SAxena (2008): "Growth Dynamics: The Myth of Economic Recovery," American Economic Review, 98, 439-457.

Cerutti, E., S. Claessens, And L. Laeven (2017): “The Use and Effectiveness of Macroprudential Policies: New Evidence," Journal of Financial Stability, 28, 203-224.

Cesa-Bianchi, A., C. L. Felipe, And A. Rebucci (2015): “Global Liquidity, House Prices, and the Macroeconomy," Journal of Money, Credit, and Banking, 301-335.

Cesa-Bianchi, A., A. Ferrero, and A. Rebucci (2018): "International Credit Supply Shocks," Journal of International Economics, 112, 219-237.

Cesa-Bianchi, A., M. H. Pesaran, and A. Rebucci (forthcoming): "Uncertainty and Economic Activity: A Multi-country Perspective," Review of Financial Studies.

Cesa-Bianchi, A. And A. Rebucci (2017): "Does Easing Monetary Policy Increase Financial Instability?" Journal of Financial Stability, 30, 111-125.

Cespedes, L. F. And R. Chang (2019): “Optimal Foreign Reserves and Central Bank Policy Under Financial Stress," Manuscript.

Céspedes, L. F., R. Chang, And A. Velasco (2017): "Financial Intermediation, Real Exchange Rates, and Unconventional Policies in an Open Economy," Journal of International Economics, 108, S76-S86. 
Chamon, M. And M. Garcia (2016): “Capital Controls in Brazil: Effective?” Journal of International Money and Finance, 61, 163-187.

Chang, C., Z. LiU, And M. M. Spiegel (2015): "Capital Controls and Optimal Chinese Monetary Policy," Journal of Monetary Economics, 74, 1-15.

Chinn, M. D. And H. Ito (2006): "What Matters for Financial Development? Capital Controls, Institutions, and Interactions," Journal of Development Economics, 81, 163-192.

Costinot, A., G. Lorenzoni, And I. Werning (2014): "A Theory of Capital Controls as Dynamic Terms-of-Trade Manipulation,” Journal of Political Economy, 122, 77-128.

Coulibaly, L. (2018): “Monetary Policy in Sudden Stop-prone Economies,” Manuscript.

DÁvila, E. AND A. KorineK (2018): "Pecuniary Externalities in Economies with Financial Frictions," Review of Economic Studies, 85, 352-395.

Davila, J., J. H. Hong, P. KRusell, and J.-V. Ríos-Rull (2012): "Constrained Efficiency in the Neoclassical Growth Model with Uninsurable Idiosyncratic Shocks," Econometrica, 80, 2431-2467.

Davis, J. S. And I. Presno (2017): “Capital Controls and Monetary Policy Autonomy in a Small Open Economy,” Journal of Monetary Economics, 85, 114-130.

De Gregorio, J., S. Edwards, And R. O. VAldes (2000): “Controls on Capital Inflows: Do They Work?” Journal of Development Economics, 63, 59-83.

De PaOli, B. AND A. LipinskA (2012): "Capital Controls: A Normative Analysis," in Federal Reserve Bank of San Francisco Proceedings, Nov, 1-36.

DenNis, Q. (1997): “The Correlates of Change in International Financial Regulation," The American Political Science Review, 91, 531-551.

Dennis, Q. And A. M. Toyoda (2008): "Does Capital Account Liberalization Lead to Growth?" Review of Financial Studies, 21, 1403-1449.

DevereuX, M. B. And C. Engel (2003): "Monetary Policy in the Open Economy Revisited: Price Setting and Exchange-Rate Flexibility," The Review of Economic Studies, 70, 765783.

Devereux, M. B., E. R. Young, And C. Yu (2018): "Capital Controls and Monetary Policy in Sudden-stop Economies," Journal of Monetary Economics.

DevereuX, M. B. And C. Yu (2017): "Exchange Rate Adjustment in Financial Crises," IMF Economic Review, 65, 528-562.

DoRnbusch, R. (2002): “Malaysia's Crisis: Was It Different?" in Preventing Currency Crises in Emerging Markets, University of Chicago Press, 441-460. 
Dornbusch, R. And S. Edwards (1990): “Macroeconomic Populism,” Journal of Development Economics, 32, 247-277.

EDWARDS, S. (2004): "Financial Openness, Sudden Stops, and Current-Account Reversals," American Economic Review, 94, 59-64.

Eichengreen, B. And A. Rose (2014): “Capital Controls in the 21st Century," Journal of International Money and Finance, 48, 1-16.

Engel, C. (2016): "Macroprudential Policy under High Capital Mobility: Policy Implications from an Academic Perspective," Journal of the Japanese and International Economies, 42, $162-172$.

Epure, M., I. Mihai, C. Minoiu, And J.-L. Peydró (2018): “Household Credit, Global Financial Cycle, and Macroprudential Policies: Credit Register Evidence from an Emerging Country,".

Erten, B., A. KorineK, And J. A. OCAmpo (forthcoming): “Capital Controls: Theory and Evidence," Journal of Economic Literature.

FAnelli, S. And L. StRaub (forthcoming): "A Theory of Foreign Exchange Interventions," Review of Economic Studies.

FARHI, E. AND I. WeRning (2014): "Dilemma not Trilemma? Capital Controls and Exchange Rates with Volatile Capital Flows," IMF Economic Review, 62, 569-605.

(2016): "A Theory of Macroprudential Policies in the Presence of Nominal Rigidities," Econometrica, 84, 1645-1704.

Federico, P., C. A. Vegh, And G. Vuletin (2014): "Reserve Requirement Policy over the Business Cycle,” Tech. rep., NBER Working Paper No. 20612.

Fernández, A., M. W. Klein, A. Rebucci, M. Schindler, And M. Uribe (2016): "Capital Control Measures: A New Dataset," IMF Economic Review, 64, 548-574.

Fernández, A., A. Rebucci, And M. URibe (2015): “Are Capital Controls Countercyclical?" Journal of Monetary Economics, 76, 1-14.

Fisher, I. (1933): “The Debt-Deflation Theory of Great Depressions," Econometrica, 337357.

Forbes, K., M. Fratzscher, T. Kostka, And R. Straub (2016): "Bubble Thy Neighbour: Portfolio Effects and Externalities from Capital Controls," Journal of International Economics, 99, 85-104.

Forbes, K., M. Fratzscher, And R. Straub (2015): “Capital-flow Management Measures: What Are They Good For?” Journal of International Economics, 96, S76-S97. 
Forbes, K. J. (2007a): "The Microeconomic Evidence on Capital Controls: No Free Lunch," in Capital Controls and Capital Flows in Emerging Economies: Policies, Practices and Consequences, University of Chicago Press, 171-202.

(2007b): "One Cost of the Chilean Capital Controls: Increased Financial Constraints for Smaller Traded Firms," Journal of International Economics, 71, 294-323.

Forbes, K. J. And M. W. Klein (2015): "Pick Your Poison: The Choices and Consequences of Policy Responses to Crises," IMF Economic Review, 63, 197-237.

FORNARO, L. (2015): "Financial Crises and Exchange Rate Policy," Journal of International Economics, 95, 202-215.

Geanakoplos, J. And H. Polemarchakis (1986): "Existence, Regularity, and Constrained Suboptimality of Competitive Allocations When the Asset Market is Incomplete," Uncertainty, Information and Communication: Essays in Honor of KJ Arrow, 3, 65-96.

Giordani, P. E., M. Ruta, H. Weisfeld, And L. Zhu (2017): “Capital Flow Deflection,” Journal of International Economics, 105, 102-118.

Gopinath, G. (2019): “A Case for An Integrated Policy Framework,” Proceedings - Economic Policy Symposium - Jackson Hole, Federal Reserve Bank of Kansas City Economic Policy Symposium.

Gopinath, G. And J. C. Stein (2018): "Banking, Trade, and the Making of a Dominant Currency," NBER Working Paper No. 24485.

Greenwald, B. C. AND J. E. Stiglitz (1986): "Externalities in Economies with Imperfect Information and Incomplete Markets," Quarterly Journal of Economics, 101, 229-264.

Grilli, V. And G. M. Milesi-Ferretti (1995): "Economic Effects and Structural Determinants of Capital Controls," IMF Staff Papers, 42, 517-551.

Han, X. AND S.-J. WEI (2018): "International Transmissions of Monetary Shocks: Between a Trilemma and a Dilemma," Journal of International Economics, 110, 205-219.

Heathcote, J. And F. Perri (2016): “On the Desirability of Capital Controls,” IMF Economic Review, 64, 75-102.

Iacoviello, M. (2005): "House Prices, Borrowing Constraints, and Monetary Policy in the Business Cycle," American Economic Review, 95, 739-764.

Ilzetzki, E., C. M. Reinhart, AND K. S. Rogoff (2019): "Exchange Arrangements Entering the Twenty-First Century: Which Anchor will Hold?" Quarterly Journal of Economics, 134, 599-646.

IMF (2000): "Capital Controls: Country Experiences with Their Use and Liberalization," Occasional Paper No. 190. 
_ (2012): "The Liberalization and Management of Capital Flows: An Institutional View,"

JeAnne, O. (2018): “Currency Wars, Trade Wars and the Global Demand,” Manuscript.

Jeanne, O. And A. KorineK (2018): "Managing Credit Booms and Busts: A Pigouvian Taxation Approach," Journal of Monetary Economics.

_ (forthcoming): "Macroprudential Regulation Versus Mopping Up after the Crash," Review of Economic Studies.

Kaminsky, G. L., C. M. Reinhart, And C. A. Vegh (2005): "When It Rains, It Pours: Procyclical Capital Flows and Macroeconomic Policies," NBER Macroeconomics Annual 2004, 11.

Keller, L. (2018): “Capital Controls and Risk Misallocation: Evidence from a Natural Experiment," Manuscript.

Kiyotaki, N. And J. Moore (1997): “Credit Cycles,” Journal of Political Economy, 105.

KLEIN, M. W. (2012): “Capital Controls: Gates versus Walls,” Brookings Papers on Economic Activity, 317-350.

Klein, M. W. And J. C. Shambaugh (2015): "Rounding the Corners of the Policy Trilemma: Sources of Monetary Policy Autonomy," American Economic Journal: Macroeconomics, 33-66.

KorineK, . (2007): "Excessive Dollar Borrowing in Emerging Markets: Balance Sheet Effects and Macroeconomic Externalities," Ph.D. Dissertation, Columbia University.

KorineK, A. (2016): "Currency Wars or Efficient Spillovers? A General Theory of International Policy Cooperation," NBER Working Paper No. 23004.

- (2018): "Regulating Capital Flows to Emerging Markets: An Externality View," Journal of International Economics, 111, 61-80.

KorineK, A. AND D. SANDRI (2016): “Capital Controls or Macroprudential Regulation?" Journal of International Economics, 99, S27-S42.

KorineK, A. AND A. SimseK (2016): “Liquidity Trap and Excessive Leverage," American Economic Review, 106, 699-738.

LiU, Z., P. WANG, AND T. ZHA (2013): "Land-Price Dynamics and Macroeconomic Fluctuations," Econometrica, 81, 1147-1184.

Lorenzoni, G. (2008): "Inefficient Credit Booms," Review of Economic Studies, 75, 809_ 833. 
MA, C. (2020): "Financial Stability, Growth and Macroprudential Policy," Journal of International Economics, 122, 103259.

MA, C., J. Rogers, And S. Zhou (2019): “The Effect of the China Connect," Manuscript.

MA, C. AND S.-J. WEI (2019): "Domestic Institutions and the Volatility of International Capital Flows," Manuscript.

Magud, N., A. Spilimbergo, And A. Werner (forthcoming): "Populism in Latin America: Economic and Institutional Consequences," IMF Working Paper.

Magud, N. E., C. M. Reinhart, And K. S. Rogoff (2018): “Capital Controls: Myth and Reality," Annals of Economics and Finance, 19, 1-47.

MendozA, E. G. (2002): "Credit, Prices, and Crashes: Business Cycles with a Sudden Stop," in Preventing Currency Crises in Emerging Markets, University of Chicago Press, 335-392.

- (2010): “Sudden Stops, Financial Crises, and Leverage," American Economic Review, $100,1941-66$.

ObSTFEld, M. AND K. S. Rogoff (1996): Foundations of International Macroeconomics, vol. 30, MIT press Cambridge, MA.

Ostry, J. D., A. R. Ghosh, M. Chamon, And M. S. Qureshi (2012): “Tools for Managing Financial-stability Risks from Capital Inflows," Journal of International Economics, 88, 407-421.

Ottonello, P. (2015): “Optimal Exchange Rate Policy under Collateral Constraints and Wage Rigidity," Manuscript.

Pasricha, G. K., M. Falagiarda, M. Bijsterbosch, And J. Aizenman (2018): “Domestic and Multilateral Effects of Capital Controls in Emerging Markets," Journal of International Economics, 115, 48-58.

REY, H. (2013): "Dilemma not Trilemma: the Global Financial Cycle and Monetary Policy Independence," Proceedings - Economic Policy Symposium - Jackson Hole, Federal Reserve Bank of Kansas City Economic Policy Symposium, 285-333.

Rogoff, K. S. And C. M. REInhart (2009): "The Aftermath of Financial Crises," American Economic Review.

SCHINDler, M. (2009): "Measuring Financial Integration: A New Data Set," IMF Staff Papers, 56, 222-238.

SChmitT-Grohé, S. AND M. URibe (2016a): "Downward Nominal Wage Rigidity, Currency Pegs, and Involuntary Unemployment," Journal of Political Economy, 124, 1466-1514.

(2016b): "Multiple Equilibria in Open Economy Models with Collateral Constraints: Overborrowing Revisited," NBER Working Paper No. 22264. 
Senay, O. And A. Sutherland (2015): "Local Currency Pricing, Foreign Monetary Shocks and Exchange Rate Policy," Open Economies Review, 633-661.

UriBe, M. (2006): “On Overborrowing,” American Economic Review, 96, 417-421.

ZeEv, N. B. (2017): "Capital Controls as Shock Absorbers," Journal of International Economics, 109, 43-67. 